\title{
A comparative evaluation of analgesic and anti-inflammatory activities of two medicinal plants rubia cordifolia and cassia fistula in wistar albino rats
}

\author{
Rajashekar Y. R.*, Narasimhamurthy K. M.
}

Department of Pharmacology, Adichunchanagiri Institute of Medical Sciences, BG Nagar, Mandya, Karnataka, India

Received: 22 February 2017

Revised: 24 February 2017

Accepted: 27 February 2017

*Correspondence to:

Dr. Rajashekar Y. R.,

Email:

rajashekar.yr@gmail.com

Copyright: (C) the author(s), publisher and licensee Medip Academy. This is an openaccess article distributed under the terms of the Creative Commons Attribution NonCommercial License, which permits unrestricted noncommercial use, distribution, and reproduction in any medium, provided the original work is properly cited.

\begin{abstract}
Background: Pain and inflammation are disabling accompaniments of many medical conditions. So, controlling both pain and inflammation assumes the top priority for the physician. Inflammation is a part of a complex biological response of vascular tissues to harmful stimuli such as pathogens, chemicals or irritants. Therapy of pain and inflammation has always been debatable.

Methods: Rats were divided into 8 groups of 6 animals of each. The antiinflammatory activity was studied with carrageenan induced rat paw edema and cotton pellet induced granuloma models. The analgesic activity was evaluated using Eddy's hot plate model. The aqueous extract of Rubia cardifolia root and Cassia fistula leaf preparations were compared with Diclofenac in both acute and sub acute inflammatory models and also in pain model.

Results: Various test result parameters were statistically analysed at $\mathrm{P}$ value $<0.5$. In Eddy's hot plate model both $\mathrm{RC}$ and $\mathrm{CF}$ preparations prolonged the response reaction time, while $\mathrm{CF}$ preparation showed longer reaction time than that of RC preparation. In carrageenan induced paw edema and cotton pellet induced granuloma models, both $\mathrm{RC}$ and $\mathrm{CF}$ preparations showed significant decrease in paw edema volume and granuloma dry weight respectively, but less than that of Diclofenac. RC preparation found to have dose dependant in inflammatory models.

Conclusions: RC root and $\mathrm{CF}$ leaf preparations were compared head to head and they have been found to have significant dose dependant analgesic activity and dose independent acute and sub acute anti inflammatory activities. Though $\mathrm{CF}$ leaf preparation appeared to be a good analgesic than RF root preparation, but failed to do so as an anti inflammatory agent in both inflammatory models. But both test preparations were not equivalent to Diclofenac in all three models.
\end{abstract}

Keywords: Anti-inflammatory, Analgesics, Adverse effects, Cassia fistula (CF) leaves, Diclofenac, Rubia cordifolia (RC) roots

\section{INTRODUCTION}

Pain and inflammation are the disabling symptoms of the most of the clinical disorders and controlling them are very much challenging task for the physician. ${ }^{1}$ According to International Association for study of pain (ISAP), Pain is an unpleasant sensory and emotional experience associated with actual and potential tissue damage or described in terms of such damage or both. ${ }^{2}$ Whereas inflammation is (latin, inflammacio, which means "to set a fire") part of the complex biological response of the body tissues to harmful stimuli such as pathogens, damaged cells or irritants. ${ }^{3}$ The characteristics of inflammation was first enunciated by Celsus and added later by Galen and Hunter. ${ }^{4}$ They include Rubor (Redness), Tumor (Swelling), Calor (Heat), Dolor (Pain) and Functio laesa (loss of function). Inflammation is considered as a mechanism of innate immunity. Inflammatory mediators initiate signaling cascades, leading to acute modulation of protein structure (i.e posttranslational change) of transducing and voltagegated ion channels, which alter function and enhance responsiveness via the action of protein kinase $\mathrm{C}^{5}{ }^{5}$ Currently available anti-inflammatory agents are 
associated with unwanted side effects and have their own limitations. It has been estimated that about $34-46 \%$ of the users of NSAIDs will sustain some gastrointestinal damage due to the inhibition of the protective COX enzyme in gastric mucosa. ${ }^{6}$

Medications to manage and treat pain and inflammation are steroidal and non-steroidal anti-inflammatory drugs (NSAIDs), opioids and adjuvant drugs like gabapentine, pregabalin and carbamazepine. ${ }^{7}$ Among all, NSAIDs are the most widely used, with basic mode of action by inhibiting pro-inflammatory enzyme cyclooxygenase (COX). ${ }^{8}$ This class of drugs comprise nonselective NSAIDs nonspecifically inhibiting both COX1 and COX2, preferentially COX-2 inhibitors. They contribute too many side effects from mild gastrointestinal to severe cardiovascular. ${ }^{9}$ Corticosteroids are used in various conditions. World health organization's (WHO) pain ladder has considered it to be effective in relieving all phases of pain. ${ }^{10}$ They are useful as adjuvant therapy for metastatic bone pain, visceral pain and neuropathic pain. ${ }^{11}$ Despite the availability of many medications for management of pain and inflammation, scope for new drug with more efficacy, potency and safety profile exists.

A known ayurvedic herb Rubia cordifolia Linn, commonly known as Indian madder, found to have antimicrobial, anticancer, analgesic, antipyretic, antiinflammatory, antiarthritic, antihelminthic, antioxidant, immunomodulating, blood purifying and diuretic properties. $^{12-14}$

Another ayurvedic plant Cassia fistula Linn, commonly known as Golden shower, has been found to have antifungal, antimicrobial, antioxidant, analgesic, antiinflammatory, antitumour, hepatoprotective and hypoglycaemic activities. ${ }^{15}$ There are limited reports showing head to head comparison of analgesic and antiinflammatory activities of these two plants and also their interactions with standard NSAIDs and that prompted the present study.

Aims and Objectives of the study were to compare the analgesic and anti-inflammatory activities of Rubia cordifolia root and Cassia fistula leaf preparations and also to study the analgesic, anti-inflammatory activities of Rubia cordifolia and Cassia fistula with diclofenac in wistar albino rats.

\section{METHODS}

Wistar albino rats weighing around $150-250 \mathrm{~g}$ of either sex were randomly selected from central animal facility, AIMS BG Nagara with following inclusion and exclusion criterion.

\section{Inclusion criteria}

1. Wistar albino rats weighing $150-250 \mathrm{~g}$ of either sex
2. Age 3-4 months

3. Animals acclimatized to the experimental conditions for about a week.

4. Healthy with normal behaviour and activity

\section{Exclusion criteria}

1. Wistar albino rats $<150 \mathrm{~g}$ and $>250 \mathrm{~g}$ and age $<3$ months and $>4$ months

2. Pregnant animals

3. Diseased animals

4. Animals previously used in other experiments

The experiment was conducted in central animal laboratory at AIMS BG Nagara between 9:00 a.m. to 4:00 p.m. The animals were kept separately in individual cages under standard lab conditions with 12 hour alternate day and night cycles and room temperature and humidity maintained as per norms, with free access to standard pellet diet and filtered water ad libitum. The food and water was removed for the duration of test period. Animals were weighed and appropriate dose of drug was administered to different groups. A total of 36 animals $(n=36)$ were used. They were divided into 6 groups of 6 animals each.

a) Eddy's hot plate model-Animals were placed on hot plate maintained at $60^{\circ} \mathrm{C}$ and were observed for either paw kicking or animal jumping and the time was noted as response reaction time in seconds at 0 , 30 and 60 minutes. Longer response reaction time indicated drug analgesic activity.

b) Carrageenan induced paw edema modelCarrageenan $1 \% 0.1 \mathrm{ml}$ was injected into subplantar region rat hind paw to produce edema. Using plethysmograph the paw edema was measured at 0 , 30, 60, 180 and 300 minutes. The acute antiinflammatory action was determined by the inhibition of paw edema volume.

c) Cotton pellet induced granuloma model- weighed cotton pellets were placed in subcutaneous tissue of rat axillary region aseptically, under sodium thiapentone anesthesia. On eighth day pellets were removed, adequately dried in hot air oven, before weighing them on scale. Reduced weight of pellets showed sub acute anti inflammatory activity.

Animals were divided into 6 groups of each animal 6 and following treatment was given per orally, depending upon their body weight.

- I group: Control (Normal saline 1ml, oral);

- II group: Standard drug (Diclofenac $13.5 \mathrm{mg} / \mathrm{kgbw}$, oral);

- $\quad$ III group: Test drug 1 (RC roots $100 \mathrm{mg} / \mathrm{kgbw}$, oral);

- IV group: Test drug 2 ( $\mathrm{RC}$ roots $300 \mathrm{mg} / \mathrm{kgbw}$, oral);

- V group: Test drug 3 (CF leaves $250 \mathrm{mg} / \mathrm{kbwg}$, oral);

- VI group: Test drug 4 (CF leaves $500 \mathrm{mg} / \mathrm{kgbw}$, oral). 
Data collected was analyzed by calculating mean and standard deviation. Tabulated mean and standard deviations were statistically analysed using student ' $\mathrm{T}$ ' test and annova test followed by post Hoc Turkey test.

\section{RESULTS}

\section{Eddy's hot plate model}

In this analgesic model, diclofenac prolonged reaction time with mean value 13.50 at 60 minutes, statistically highly significant when compared with control. RC preparation prolonged reaction time significantly with mean values 8.16 and 8.50 at $100 \mathrm{mg} / \mathrm{kgbw}$ and $300 \mathrm{mg} / \mathrm{kgbw}$ respectively, but not that of diclofenac treated group. Whereas CF preparation at $250 \mathrm{mg} / \mathrm{kgbw}$ and $500 \mathrm{mg} / \mathrm{kgbw}$ with the mean values 7.50 and 9.33 , showed significant analgesic activity in a dose dependent manner.

Table 1: Reaction time (in seconds) comparison between groups at $60 \mathrm{~min}$.

\begin{tabular}{|c|c|c|c|c|c|c|c|}
\hline \multirow{2}{*}{\multicolumn{2}{|c|}{ Control }} & $\mathbf{N}$ & \multicolumn{2}{|c|}{ Mean } & \multicolumn{2}{|l|}{ SD } & \% inhibition \\
\hline & Control & 6 & \multicolumn{2}{|c|}{5.83} & \multicolumn{3}{|c|}{1.169} \\
\hline \multicolumn{2}{|c|}{ Standard- diclo } & 6 & \multicolumn{2}{|c|}{13.50} & \multicolumn{2}{|c|}{2.738} & $131.44 * * *$ \\
\hline \multicolumn{2}{|c|}{$\begin{array}{l}\text { Rubia cardifolia } \\
100 \mathrm{mg} / \mathrm{kgbw}\end{array}$} & 6 & \multicolumn{2}{|c|}{8.16} & \multicolumn{2}{|l|}{1.94} & $40.01 *$ \\
\hline \multicolumn{2}{|c|}{$\begin{array}{l}\text { Rubia cardifolia } \\
300 \mathrm{mg} / \mathrm{kgbw}\end{array}$} & 6 & \multicolumn{2}{|c|}{8.50} & \multicolumn{2}{|l|}{2.88} & $45.72 *$ \\
\hline \multicolumn{2}{|c|}{$\begin{array}{l}\text { Cassia fistula } \\
250 \mathrm{mg} / \mathrm{kgbw}\end{array}$} & 6 & \multicolumn{2}{|c|}{7.50} & \multicolumn{2}{|l|}{1.64} & $28.58 *$ \\
\hline \multicolumn{2}{|c|}{$\begin{array}{l}\text { Cassia fistula } \\
500 \mathrm{mg} / \mathrm{kgbw}\end{array}$} & 6 & \multicolumn{2}{|c|}{9.33} & \multicolumn{2}{|l|}{1.86} & $60.00 * *$ \\
\hline Total & & 36 & & & 3.09 & & \\
\hline \multicolumn{8}{|l|}{ ANOVA } \\
\hline \multicolumn{8}{|l|}{$60 \mathrm{~min}$} \\
\hline & \multicolumn{2}{|c|}{$\begin{array}{l}\text { Sum of } \\
\text { squares }\end{array}$} & Df & \multicolumn{2}{|c|}{$\begin{array}{l}\text { Mean } \\
\text { square }\end{array}$} & $\mathrm{F}$ & $P$ value \\
\hline $\begin{array}{l}\text { Between } \\
\text { groups }\end{array}$ & \multicolumn{2}{|c|}{200.139} & 5 & \multicolumn{2}{|c|}{40.028} & 8.862 & $<0.001 *$ \\
\hline $\begin{array}{l}\text { Within } \\
\text { groups }\end{array}$ & \multicolumn{2}{|c|}{135.500} & 30 & \multicolumn{2}{|c|}{4.517} & & \\
\hline Total & \multicolumn{2}{|c|}{335.639} & 35 & & & & \\
\hline
\end{tabular}

Post Hoc Tukey: 1 vs 2, 2 vs 3, 2 vs 4, 2 vs 5 and 2 vs 6

\section{Carrageenan induced rat paw edema model}

In this acute inflammatory model, diclofenac significantly reduced rat paw edema at 30,60.180 and 300 minutes (results at 300 minutes shown in the table). $\mathrm{CF}$ preparation in both $250 \mathrm{mg} / \mathrm{kgbw}$ and $500 \mathrm{mg} / \mathrm{kgbw}$ did not significantly reduce paw edema at any point of time of the experiment with mean values 1.75 and 1.96 respectively at 300 minutes. RC preparation inhibited paw edema by $3.6 \%$ only at $100 \mathrm{mg} / \mathrm{kgbw}$ dose, whereas $300 \mathrm{mg} / \mathrm{kgbw}$ dose significantly inhibited the same to the extent of $21.05 \%$, showing its acute anti-inflammatory activity at higher dose.
Table 2: Carrageenan induced rat paw edema (in $\mathrm{ml}$ ) at 300 minutes.

\begin{tabular}{|c|c|c|c|c|c|}
\hline \multirow{2}{*}{ Control } & $\mathbf{N}$ & \multicolumn{2}{|r|}{ Mean } & SD & \%inhibition \\
\hline & 6 & \multicolumn{2}{|r|}{1.900} & 0.232 & \\
\hline Standard- diclo & 6 & & 0.933 & $0.060 *$ & $51.05^{*}$ \\
\hline \multicolumn{2}{|l|}{$\begin{array}{l}\text { Rubia cardifolia } \\
100 \mathrm{mg} / \mathrm{kgbw}\end{array}$} & \multicolumn{2}{|r|}{1.833} & 0.140 & 3.68 \\
\hline \multicolumn{2}{|l|}{$\begin{array}{l}\text { Rubia cardifolia } \\
300 \mathrm{mg} / \mathrm{kgbw}\end{array}$} & \multicolumn{2}{|r|}{1.500} & $0.164 *$ & $21.05^{*}$ \\
\hline \multicolumn{2}{|l|}{$\begin{array}{l}\text { Cassia fistula } \\
250 \mathrm{mg} / \mathrm{kgbw}\end{array}$} & \multicolumn{2}{|r|}{1.758} & 0.171 & 7.46 \\
\hline \multicolumn{2}{|l|}{$\begin{array}{l}\text { Cassia fistula } \\
500 \mathrm{mg} / \mathrm{kgbw}\end{array}$} & \multicolumn{2}{|r|}{1.966} & 0.060 & 3.51 \\
\hline \multicolumn{6}{|l|}{ ANOVA } \\
\hline \multicolumn{6}{|l|}{ 300minutes } \\
\hline & $\begin{array}{l}\text { Sum of } \\
\text { squares }\end{array}$ & $\mathrm{df}$ & $\begin{array}{l}\text { Mean } \\
\text { square }\end{array}$ & $\mathrm{F}$ & $P$ value \\
\hline $\begin{array}{l}\text { Between } \\
\text { groups }\end{array}$ & 4.858 & 7 & 0.694 & 30.577 & $<0.001 *$ \\
\hline $\begin{array}{l}\text { Within } \\
\text { groups }\end{array}$ & 0.908 & $\begin{array}{l}4 \\
0\end{array}$ & \multicolumn{2}{|l|}{0.023} & \\
\hline Total & 5.766 & $\begin{array}{l}4 \\
7\end{array}$ & & & \\
\hline
\end{tabular}

Post Hoc Tukey: 1 vs 2,1 vs 4,2 vs 3,2 vs 4,2 vs 5,2 vs 6,2 vs 7,2 vs 8,3 vs 4,4 vs 6,4 vs $8^{*}$

\section{Cotton pellet induced granuloma model}

Table 3: Cotton pellet induced granuloma (in mg) between and within groups.

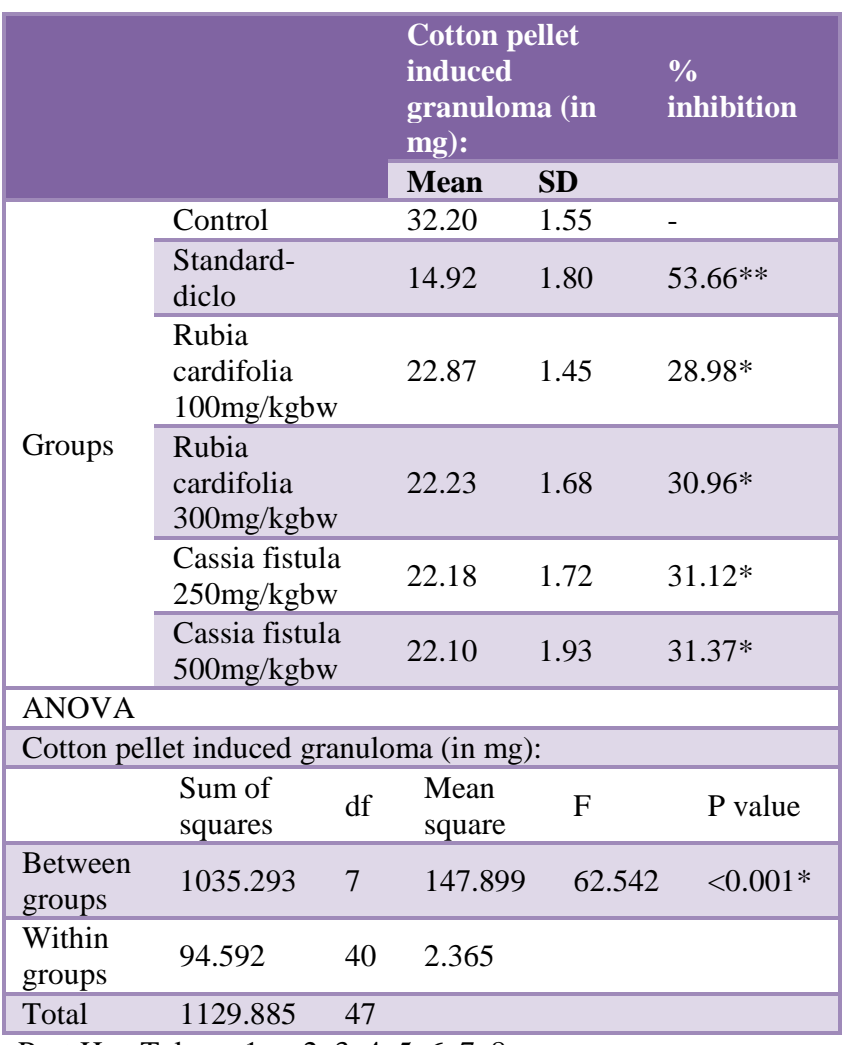

Post Hoc Tukey: 1 vs 2, 3, 4, 5, 6, 7, 8

2 vs $3,4,5,6,7,8$

3 vs 7,8

4 vs 7,5 vs 7,6 vs 
In this model also, both RC and CF preparations could not be as active as diclofenac, which showed the highest $\%$ inhibition of 53.66. RC preparation decreased granuloma weight with mean value of 22.87 and 22.23 with doses $100 \mathrm{mg} / \mathrm{kgbw}$ and $300 \mathrm{mg} / \mathrm{kgbw}$ respectively. CF preparation in both $250 \mathrm{mg} / \mathrm{kgbw}$ and $500 \mathrm{mg} / \mathrm{kgbw}$ doses decreased the granuloma weight with values 22.18 and 22.10 respectively with almost similar \% of inhibition of 31 . These values suggest that $\mathrm{CF}$ preparations have significant sub acute anti-inflammatory action in a dose independent manner.

\section{DISCUSSION}

Pain and inflammation are dynamic processes considered as the protective mechanisms lead to chronic inflammatory state when deregulated. The analgesic system block pain signals at the initial entry point that is dorsal horn of spinal cord and objective of our study was to find the central analgesic activity of test drugs using Eddy's hot plate model. In Eddy's hot plate method, standard diclofenac found to be very effective analgesic at 30 minute and 60 minutes as a well-known fact. Cassia fistula $(\mathrm{CF})$ preparation showed dose dependent and time dependent analgesic activity at 30 and 60 minutes, whereas Rubia cordifolia (RC) preparation did not show dose dependent analgesic activity but, showed similar analgesic activity at both higher and lower doses.

Our study showed that RC and CF preparations possess good analgesic effect in Eddy's hot plate method probably by central action, consistent with other previous studies. In our study, we also found that CF preparation in higher dose $(500 \mathrm{mg} / \mathrm{kg})$ exhibited maximum analgesic activity at $60 \mathrm{~min},(\mathrm{P}<0.01)$ and it was comparatively higher than that of standard diclofenac and slightly higher than that OF RC in higher dose $(300 \mathrm{mg} / \mathrm{kg})$. These analgesic models involved the latency period, percent inhibition and mean reaction time to a painful stimulus. The stimulus in this model is thermal (Eddy's hot plate). Centrally acting analgesics not only raise the threshold for pain, but also alter the physiological response to pain and suppress the patient's anxiety and apprehension. Perindopril possibly exhibits its analgesic activity both by central analgesic activity (Eddy's hot plate and tail clip) through release of beta- endorphin and enkephalin in the spinal cord, increasing the angiotensin 1-7 levels and also by peripheral analgesic action (writhing method) through inhibition of COX 2 and PGE2. ${ }^{17}$

According to a study, the 3-substituted indole derivatives played a vital role as anti-inflammatory and analgesic agents compared to indomethacin and were found to possess potent anti-inflammatory and analgesic activities using same above mentioned screening models. ${ }^{18}$ The most widely used primary test to screen new antiinflammatory agents measures the ability of a compound to reduce local edema induced in rat paw by injection of an irritant agent i.e. carrageenan. The development of edema described as biphasic event. The early phase (1- 2h) of carrageenan model is mainly attributed to the release of histamine, serotonin and increased synthesis of prostaglandins into damaged tissue surroundings. The late phase which is accelerating the phase of swelling, is sustained by the release of prostaglandins-like substances and mediated by bradykinin, protease, leukotriens, lysosomes, polymorphonuclear cells and prostaglandins produced by tissue macrophages. ${ }^{19}$ Administration of the RC $(100 \mathrm{mg} / \mathrm{kg}, 300 \mathrm{mg} / \mathrm{kg})$ and CF $(250 \mathrm{mg} / \mathrm{kg}$, $500 \mathrm{mg} / \mathrm{kg}$ ) preparations suppressed the oedematous response in a dose dependant manner. However, the observed effect of higher higher dose of CF preparation $\mathrm{CF}$ preparation is lesser than that of standard diclofenac. Based on the results obtained, it is likely that the mechanism of both RC and CF preparations are similar to that of NSAID's (Non-steroidal anti-inflammatory drugs) i.e. inhibition of prostaglandin biosynthesis and both play a crucial role as a protective factor against the carrageenan induced acute inflammation. In this study, we found that RF and CF preparations have antiinflammatory properties as shown in previous studies. Among the two medicinal plants, RC preparation was found to have more anti inflammatory properties compared to $\mathrm{CF}$ preparation. However the observed effect of RC preparation is lesser than that of standard diclofenac but more than the higher dose of $\mathrm{CF}$ preparation. This is in contrast with analgesic model where CF preparation in higher dose was found to be more analgesic than that of RC preparation. Based on the results obtained it can be presumed that both $\mathrm{RC}$ and $\mathrm{CF}$ preparations appeared to act by inhibiting the release and poorly sustaining the levels of chemical mediators especially prostaglandins.

The cotton pellet- induced granuloma is widely used to assess the transudative and proliferative components of chronic inflammation. ${ }^{20}$ The inflammatory granuloma is a typical feature of sub acute inflammatory reaction. ${ }^{21}$ Both test and standard drugs used in this study elicited significant inhibitory activity on the dry weight of granuloma, which projects the effect of test substances on the proliferative phase rather than transudative phase of inflammation. In this present study, we found that antigranuloma activity of diclofenac and test drugs was significantly more than that of saline control, but test drugs failed to show sub acute anti-inflammatory activity in a dose dependent manner. This observation in contrast with Kigella pinnata study, where $\mathrm{K}$ pinnata dose dependently suppressed acute and sub acute inflammation.

Present study finding supports the previous claims and provides a scientific basis for anti-inflammatory effects of these compounds in inflammatory diseases. So it is hoped that these studies will stimulate further efforts towards the development of new and urgently needed medications for the treatment of inflammatory diseases. In our comparative study, we found that $\mathrm{CF}$ preparation appeared to be a good dose dependent analgesic with less anti-inflammatory action whereas $\mathrm{RC}$ and $\mathrm{CF}$ 
preparations were found to have dose independent antiinflammatory actions in the both models. More studies are required to explain the basis for this differentiating action of these two plants.

\section{CONCLUSION}

With the background of increasing prescription of NSAIDs and their toxicity profile, new herbal products with no or minimal tolerable toxicity are need of the hour. Rubia cordifolia (RC) and Cassia fistula (CF) preparations are extensively studied and found to have very good analgesic and anti-inflammatory properties. When compared head to head they have been found to be effective in the analgesic and anti-inflammatory models but less than that of diclofenac. CF preparation has been found to have comparatively good analgesic action when compared with RC preparation, whereas RC preparation has greater acute and chronic anti-inflammatory actions than $\mathrm{CF}$ preparation. Further studies are required to explore the interaction between diclofenac and $\mathrm{RC}$ and CF preparations, so fixed dose combination of both with diclofenac could be considered. Such fixed dose combination may have greater efficacy and potency with lesser toxicity of Diclofenac and this combination could be useful in various painful, inflammatory and arthritic conditions with good tolerability. However further clinical studies are required to confirm and to throw more light on the same.

\section{Funding: No funding sources} Conflict of interest: None declared

Ethical approval: The study was approved by the Institutional Ethics Committee

\section{REFERENCES}

1. Rang HP, Dale MN, Ritter JM, Henderson G. Analgesic Drugs. In: Rang and Dale's Pharmacology. 7th ed. Edinburgh: Elsevier Churchill Livingstone; 2012:503-524.

2. Cole BE. Pain Management: Classifying, Understanding and Treating Pain. Hospital Physician; 2002:23-30.

3. Ferrero-Miliani L, Nielsen $\mathrm{OH}$, Anderson PS, Girardin SE. Chronic inflammation: importance of NOD2 and NALP3 in interleukin-1beta generation. Clin. Exp. Immunol. 2007;147(2):227-35.

4. Anderson WAD. Inflammation and Healing. Pathology, $9^{\text {th }}$ Edition, C.V. Mosby co. 1990;1:67.

5. Walker SM. Introduction of pain. In: Macintyre PE, Walker SM, Rawbotham DJ, editors. Clinical pain Management: Acute pain. $2^{\text {nd }}$ Ed. Hodder \& Stoughton: London; 2008:20-31.

6. Rang HP, Dale MM, Ritter JM, Henderson G. Antiinflammatory and immunosuppressant drugs. In: Rang and Dale's Pharmacology, $7^{\text {th }}$ edition. Edinburgh: Elseveir Churchill Livingstone; 2008:318-34.
7. Breivik H, Collett B, Ventafridda V, Cohen R, Gallacher D. Survey of chronic pain in Europe; Prevalence, impact on daily life and treatment. Eur J Pain. 2006;10:287-333.

8. Wane JR, Bakhle YS, Botting RN. Cyclooxygenases 1 and 2. Annual Review of pharmacology and toxicology. 2015;38:97-120.

9. CKS, Lirk P, Tan CH, Seymour RA. EvidenceBased Update on Nonsteroidal Anti-Inflammatory Drugs. Clin Med Res. 2007;5(1):19-34.

10. World Health Organization. WHO's Pain ladder. Geneva, Switz: World Health Organization; 2010. Available from: www.who.int/cancer/palliative/painladder/en/.Access ed 2015 july 25.

11. Watanabe S, Bruera E. Corticosteroids as adjuvant analgesics. J Pain Symptom Manage. 1991;9(7):4425.

12. Sengupta R, Sheorey SD, Hinge MA. Analgesic and Anti-inflammatory Plants: An Updated Review. International Journal of pharmaceutical sciences Review and Research. 2012;12(2):114-19.

13. Kasture SB, Kasture VS, Chopde CT. Antiinflammatory activity of Rubia Cordifolia roots. Journal of Natural Remedies. 2001;(1/2):111-15.

14. Joharapurkar AA, Deode NM, Zambad SP, Umathe SN. Immunomodulatory Activity Of Alcoholic Extract Of Rubia Cordifolia Linn. Indian Drugs. 2003;40(3):179-81.

15. Neelam C, Ranjan B, Komal S, Nootan C. Review on cassia fistula. Int $\mathbf{J}$ Res Ayur Pharmacy. 2011;2(2):426-30.

16. Mohan H. In: Harsh Mohan's text book of pathology. $6^{\text {th }}$ edition. New Delhi: JAYPEE Brothers Medical Publishers private limited; 2010.

17. Suresha RN, Amoghimath S, Vaibhavi PS, Shruthi SL, Jayanthi MK, Kalabharathi HL. Evaluation of analgesic activity of perindopril in albino mice. J Adv Pharm Technol Res. 2014;5(3):129-33.

18. Radwan MAA, Ragab EA, Sabry NM, El-Shenawy SM. Synthesis and biological evaluation of new 3substituted indole derivatives as potential antiinflammatory and analgesic agents. Bioorg Med Chem. 2007;15:3832-41.

19. Parmar N, Rawat M, Kumar T. Evaluation of antiinflammatory potential of Kigelia pinnata leaf extract in wistar rats. Asia $\mathrm{N} J$ Pharm Clin Res. 2012;5(1):95-7.

20. Winter CA, Porter CC. Effect of alterations in the side chain upon anti-inflammatory and liver glycogen activities of hydrocortisone esters. J Am Pharm Assoc Sci Educ. 1957;46:515-19.

21. Spector WG. The Granulomatous Inflammatory Exudate. Int Rev Exp Pathol. 1969;8:51-5.

Cite this article as: Rajashekar YR,

Narasimhamurthy KM. A comparative evaluation of analgesic and anti-inflammatory activities of two medicinal plants rubia cordifolia and cassia fistula in wistar albino rats. Int J Basic Clin Pharmacol 2017;6:802-6. 